
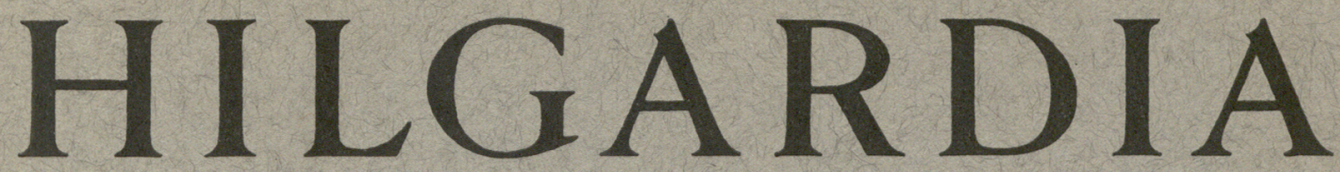

A Journal of Agricultural Science Published by the California Agricultural Experiment Station

\title{
INHERITANCE OF RESISTANCE TO THE PEA APHID IN ALFALFA HYBRIDS
}

L. G. JONES, FRED N. BRIGGS, and R. A. BLANCHARD

\section{INHERITANCE OF RESISTANCE TO SCALD IN BARLEY}

O. C. RIDDLE and FRED N. BRIGGS

\section{PHYSIOLOGIC AND GENETIC STUDIES WITH} THE STRIPE DISEASE IN BARLEY COIT A. SUNESON 


\section{In this issue:}

Inheritance of Resistance to the Pea Aphid in Alfalfa Hybrids 9

The pea aphid has caused varying amounts of damage in alfalfa fields, the damage often being severe in the Antelope Valley of California.

A number of undamaged alfalfa plants collected in this region proved to be heterozygous for resistance. A homozygous resistant plant derived from one of these was crossed with a susceptible plant, and the inheritance of resistance was studied in the $F_{2}$ and $F_{3}$ generations.

Resistance resulted from a dominant and a recessive gene. They were linked, with a crossover value of 28 per cent indicated.

Inheritance of Resistance to Scald in Barley . . . . 19

A study of the genetics of resistance to scald in barley was carried out in the field and in the greenhouse at Davis, California.

La Mesita differed from susceptible Atlas by a single dominant gene for resistance to scald.

Trebi and California No. 1311 have both a dominant and a recessive gene for resistance.

The genetic analysis of Turk was incomplete. Six lines were extracted from Turk $\times$ Atlas, which had the same high resistance as Turk. They all gave monohybrid ratios when crossed again with Atlas. These were used in the breeding of scald-resistant Atlas 46.

The single gene extracted from Turk appeared to be identical with the dominant gene found in La Mesita, Trebi, and California No. 1311.

Physiologic and Genetic Studies with the Stripe Disease in Barley . . . . . . . . . . . . 29

Male-sterile barley has become a useful tool for study of barley stripe. The disease does not reduce germination. Expression of the disease may be conditioned by the amount of growth from the spore during development of the seed, or by the season of planting. Two types of physiologic specialization in the causal fungus were identified.

Four sources of genetic resistance, involving at least six different genes, were recognized. Resistance was dominant in Hannchen, partially dominant in Trebi, recessive in Club Mariout, and weak in male-sterile. 


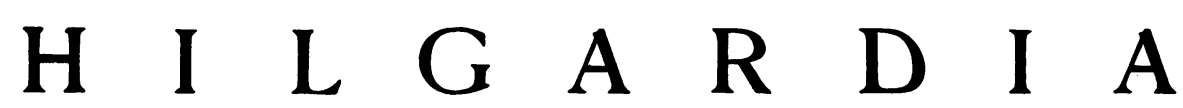

A lournal of Agricultural Science Published by the California Agricultural Experiment Station

VoL. 20

JUNE, 1950

No. 2

\section{INHERITANCE OF RESISTANCE TO THE PEA APHID IN ALFALFA HYBRIDS ${ }^{1}$}

\section{G. JONES, ${ }^{2}$ FRED N. BRIGGS, ${ }^{3}$ and R. A. BLANCHARD ${ }^{4}$}

THE PEA APHID Macrosiphum pisi (Kltb.) has at times caused severe damage to alfalfa (Medicago sativa L.) in certain areas in California, western Nevada, and elsewhere in the United States. In most of these sections, serious damage occurs at irregular intervals, the amount being largely dependent upon weather conditions during the winter and early spring. However, in the Antelope Valley of southern California, some damage has occurred regularly since 1924 . During some seasons, 90 per cent of the fields have been damaged; during others, as few as 10 per cent have been affected. With a severe infestation, the first crop is a total loss, and the second is slow to develop because the plants are weakened by the aphids.

In the Antelope Valley and elsewhere, most of the known methods of insect control have been tried without pronounced success. Although grazing the fields immediately after the insects first appear has reduced losses, the isolation or breeding of resistant varieties seemed to offer the only satisfactory method of eliminating this aphid damage. Insect resistance in plants has been recognized for a long time. Blanchard and Dudley $(1934)^{5}$ were the first to report resistance to aphids in alfalfa. The genetics of resistance to insects in plants has engaged the attention of a number of investigators. The literature on the whole subject of insect resistance as related to crop plants was reviewed by Bigger (1943), Jones (1943), Dahms (1943), Blanchard (1943), and Painter (1943), in a symposium at the Annual Meeting of the American Society of Agronomy. Comparatively few cases were noted where a satisfactory genetic analysis of insect resistance has been made. No such case was reported for alfalfa.

A survey of badly infested fields in the Antelope Valley region revealed occasional plants that showed little or no damage. From 1930 to 1933, a num-

\footnotetext{
${ }^{1}$ Received for publication September 29, 1949.

' Formerly Entomologist, United States Bureau of Entomology and Plant Quarantine, Agricultural Research Administration.

${ }^{3}$ Professor of Agronomy, University of California, and Agronomist in the California Agricultural Experiment Station.

- Entomologist, United States Bureau of Entomology and Plant Quarantine, Agricultural Research Administration.

"See "Literature Cited" for citations, referred to in the text by author and date.
} 
ber of such plants were transferred to an alfalfa nursery near Sacramento. Some of these proved to be susceptible, but others were heterozygous for resistance as determined by progeny tests. The inheritance of resistance to the pea aphid for one of these plants, no. 334, has been studied in considerable detail. The results are reported in this paper.

\section{PLANTS CHOSEN FOR STUDY}

The alfalfa plants brought from the Antelope Valley were characteristically Common Chilean, the variety normally grown there. A number proved to be susceptible, while others were heterozygous for resistance. Plant no. 334 was selected for a detailed study because initial data suggested that it was segregating for a single factor for resistance. Additional data from the first and second selfed generations, which are equivalent to $\mathrm{F}_{2}$ and $\mathrm{F}_{3}$ generations in regard to the segregation of the character under consideration, failed to confirm this theory. Furthermore, the data did not suggest any other satisfactory genetic interpretation. Since the classification of some plants had been unsatisfactory, a change in technique was worked out, which we hoped would give more certain classification.

For further study, one of the resistant $\mathrm{F}_{2}$ plants, no. 334-19, which, on the basis of $\mathrm{F}_{3}$ and $\mathrm{F}_{4}$ progeny tests, proved to be homozygous and highly resistant, was crossed reciprocally with a susceptible plant, no. 3344, of the same variety. From this cross, $503 \mathrm{~F}_{2}$ plants were tested for resistance. Although an attempt was made to get selfed seed from all of these plants, sufficient seed for a progeny test was obtained on only 256 of them.

\section{METHODS OF TESTING FOR RESISTANCE}

Original Technique. In testing the progeny of plant no. 334 for aphid resistance, the seedlings were grown singly or in groups of not more than four in 10 -inch pots and were covered with a cylindrical 18-mesh screen-wire cage. When the plants were an inch and a half or more tall and appeared to be growing rapidly, four or five female aphids were introduced into each cage. They were kept in the cage until a population large enough to damage the plant had accumulated or until the plants had demonstrated their resistance. The aphids multiplied rapidly on checks and other susceptible plants and did considerable damage in a week or 10 days. There was some variation in the rate of reproduction under different stages and conditions of plant growth, especially at different temperatures. Maximum populations developed only at temperatures that were high enough to insure the growth of succulent plants.

Aphids were unable to maintain themselves on the most resistant plants, although they usually bore several nymphs during the first few days. They lived from 4 to 15 days, depending upon the conditions of growth. At temperatures most suitable for rapid growth of the plants, they lived only a short time. The aphids reacted to feeding on resistant plants in a fairly uniform and characteristic way. After 1 or 2 days they became restless, some of them leaving the plants and crawling about the cage. The body color changed from pea green to blue green, and the abdomen became shrunken with a white fringe around the margin. The aphids died soon thereafter. 
The fungus disease Entomophthora aphidis, common among aphids, was encountered from time to time. Aphids dead from this disease can be distinguished from those killed by feeding on resistant plants or from overcrowding.

Many plants showed an intermediate degree of infestation even under apparently favorable growth conditions. This ranged from a quite small population to one almost, if not entirely, equal to the lower limit obtained on the susceptible checks. Considerable uncertainty arose as to the proper classification of these plants.

Revised Technique. Before the progeny of resistant no. 334-19 $\times$ susceptible ,no. 3344 was tested, an effort was made to find means of assuring a more positive classification and thus permitting accurate differentiation between resistant and susceptible plants. Single plants were caged, and one secondinstar nymph was introduced. The rate of nymph production and the length of the production period were used as measures of resistance. On plants of the resistant parent, second-instar nymphs usually failed to reach maturity in the normal time and upon maturity produced few nymphs or none at all. The length of life did not exceed 9 days. On plants of the susceptible parent, from 4 to 9 nymphs were produced per day for a period of 10 to 15 days. $F_{2}$ plants that appeared to be resistant on first test were reinfested to make certain that the classification was correct.

\section{RESULTS OF PROGENY TESTS}

The resistant parent no. 334-19 was selected from the progeny of no. 334, a heterozygous plant brought in from the Antelope Valley, on the basis of high resistance in the first, second, and third inbred generations. Secondinstar aphids, caged singly with individual progeny plants of plant no. 334-19, usually failed to produce nymphs (table 1 ) but occasionally produced a small population during a period of 7 to 9 days. Under similar conditions, the progeny of susceptible parent plant no. 3344 produced an average of more than 5 per day during a period of 10 to 15 days.

Reciprocal crosses between resistant plant no. 334-19 and susceptible plant no. 3344 were made in 1935 . Ten $\mathrm{F}_{1}$ plants were tested and found to be almost as resistant as no. 334-19. These plants were placed in a large cage for the purpose of obtaining selfed seed. The flowers were tripped at 4-day intervals throughout the flowering period. The resulting set of seed was satisfactory.

Resistance in $\mathbf{F}_{2}$. From this seed, $503 \mathrm{~F}_{2}$ plants were tested individually for reaction to aphids; 262 were from one plant of no. 334-19 $\times$ no. 3344 ; and 241 were from one plant of the reciprocal cross. Aphid production ranged from 0.0 to 8.9 per day, with no difference between reciprocal crosses. The $\mathrm{F}_{2}$ data are shown in table 1 .

The revised technique differentiated clearly between the resistant and susceptible parents when average values are considered. However, when individual plants are taken into account, it will be seen that the number of nymphs on one resistant plant approached the lower limit of those found on susceptible plants. If all plants with an average of three or more nymphs per day are considered susceptible, as is indicated by the reaction of the susceptible parent plants, the data suggest a single dominant factor for resistance with 
a ratio of $377: 126$, where one of $377.25: 125.75$ is expected. In almost every case where $\mathrm{F}_{2}$ plants had from 3 to 4 nymphs in the first test, they were retested to verify their classification. Retesting was not done for the parents shown. When length of productive period is taken into account, it is believed that four aphids per day is a better value than three for separating resistant from susceptible plants. This value gives 408 resistant to 95 susceptible, figures very close to the 408.7 to 94.3 expected on the basis of the $13: 3$ ratio that would result from one dominant and one recessive resistant factor. Neither ratio is borne out by the $\mathrm{F}_{3}$ data. The segregation products show, however, that one dominant and one recessive gene for resistance are present.

TABLE 1

NYMPHS PRODUCED BY ONE APHID ON $\mathrm{F}_{2}$ AND $\mathrm{P}_{1}$ PLANTS

\begin{tabular}{|c|c|c|c|}
\hline $\begin{array}{l}\text { Nymphs produced per plant } \\
\text { per day }\end{array}$ & $\mathrm{F}_{2}$ plants & $\begin{array}{c}\mathrm{P}_{1} \text { plants of } \\
\text { resistant } \\
\text { parent } \\
\text { no. 334-19 }\end{array}$ & $\begin{array}{c}\mathrm{P}_{1} \text { plants of } \\
\text { susceptible } \\
\text { parent } \\
\text { no. } 3344\end{array}$ \\
\hline $0.0 \ldots \ldots \ldots \ldots \ldots \ldots \ldots \ldots$ & 152 & 25 & . \\
\hline $0.1-0.9 \ldots \ldots \ldots \ldots \ldots \ldots \ldots \ldots \ldots \ldots \ldots \ldots \ldots$ & 58 & 2 & .. \\
\hline $1.0-1.9 \ldots \ldots \ldots \ldots \ldots \ldots \ldots \ldots \ldots \ldots \ldots$ & 96 & 2 & .. \\
\hline $2.0-2.9 \ldots \ldots \ldots \ldots \ldots \ldots \ldots \ldots \ldots \ldots \ldots \ldots$ & 71 & 1 & .. \\
\hline 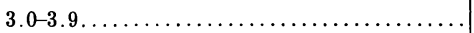 & 31 & .. & 4 \\
\hline 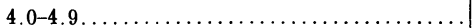 & 43 & $\ldots$ & 8 \\
\hline $5.0-5.9 \ldots \ldots \ldots \ldots \ldots \ldots \ldots \ldots \ldots \ldots \ldots \ldots$ & 24 & .. & 12 \\
\hline $6.0-6.9 \ldots \ldots \ldots \ldots \ldots \ldots \ldots \ldots \ldots \ldots \ldots \ldots \ldots \ldots$ & 14 & .. & 3 \\
\hline $7.0-7.9 \ldots \ldots \ldots \ldots \ldots \ldots \ldots \ldots \ldots \ldots \ldots \ldots$ & 10 & .. & 1 \\
\hline 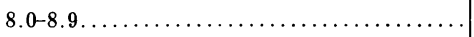 & 4 & .. & 2 \\
\hline
\end{tabular}

Percentages of Susceptible Plants in $\mathbf{F}_{3}$ Families. An attempt was made to self all $503 \mathrm{~F}_{2}$ plants in order to get seed for progeny tests. As is usual with alfalfa, considerable difficulty was experienced in getting seed. Some plants set no seed, and others produced too few to be useful. In all, 256 plants yielded enough seed to permit a progeny test. The number of plants in each progeny ranged from 8 to 70 , with an average of 25 . Some consideration was given to dropping families represented by fewer than 15 plants, but this procedure did not alter the final conclusions.

The percentage of susceptible plants in these $256 \mathrm{~F}_{3}$ families, together with their $\mathrm{F}_{2}$ classification according to the average number of nymphs produced on them, is shown in table 2. Plants were rated as susceptible if they had an average of four or more nymphs per day over a period of 10 or more days.

Analysis of Genes from $\mathbf{F}_{3}$ Results. Among the $\mathrm{F}_{3}$ populations, there are families homozygous for resistance and for susceptibility to aphid attack, às well as families that may be considered as segregating in $3: 1$ and $1: 3$ ratios (table 3 ). Such a distribution could result only from a dominant and a recessive gene. The $\mathrm{F}_{2}$ classification was only partly correct, and the proportion of segregating and homozygous $\mathrm{F}_{3}$ families is not in accordance with expectation on the basis of two independent genes.

Forty-four of the $\mathrm{F}_{2}$ parents had four or more nymphs and were consequently classed as susceptible (table 3 ). These plants would be expected to 
TABLE 2

$\mathrm{F}_{3}$ FAMILIES CLASSIFIED BY PERCENTAGES OF SUSCEPTIBLE PLANTS

\begin{tabular}{|c|c|c|c|c|c|c|c|c|c|c|c|c|c|c|c|c|c|c|c|c|c|c|}
\hline \multirow{2}{*}{$\begin{array}{c}\text { Average } \\
\text { nymphs } \\
\text { produced } \\
\text { per day } \\
\text { on } \mathrm{F}_{2} \\
\text { parents }\end{array}$} & \multicolumn{22}{|c|}{ Number of $F_{3}$ families according to percentage of susceptible plants } \\
\hline & $\begin{array}{l}0.0 \\
\text { pet. }\end{array}$ & \begin{tabular}{|c|}
0.1 \\
to \\
4.9 \\
pet.
\end{tabular} & $\begin{array}{c}5.0 \\
\text { to } \\
9.9 \\
\text { pet. }\end{array}$ & $\mid \begin{array}{c}10.0 \\
\text { to } \\
14.9 \\
\text { pet. }\end{array}$ & $\begin{array}{c}15.0 \\
\text { to } \\
19.9 \\
\text { pct. }\end{array}$ & $\mid \begin{array}{c}20.0 \\
\text { to } \\
24.9 \\
\text { pct. }\end{array}$ & $\mid \begin{array}{c}25.0 \\
\text { to } \\
29.9 \\
\text { pct. }\end{array}$ & $\begin{array}{c}30.0 \\
\text { to } \\
34.9 \\
\text { pct. }\end{array}$ & $\mid \begin{array}{c}35.0 \\
\text { to } \\
39.9 \\
\text { pct. }\end{array}$ & $\begin{array}{c}40.0 \\
\text { to } \\
44.9 \\
\text { pct. }\end{array}$ & $\begin{array}{c}45.0 \\
\text { to } \\
49.9 \\
\text { pct. }\end{array}$ & $\begin{array}{c}50.0 \\
\text { to } \\
54.9 \\
\text { pct. }\end{array}$ & $\begin{array}{c}55.0 \\
\text { to } \\
59.9 \\
\text { pct. }\end{array}$ & $\mid \begin{array}{c}60.0 \\
\text { to } \\
64.9 \\
\text { pct. }\end{array}$ & $\mid \begin{array}{c}65.0 \\
\text { to } \\
69.9 \\
\text { pct. }\end{array}$ & $\mid \begin{array}{c}70.0 \\
\text { to } \\
74.9 \\
\text { pet. }\end{array}$ & \begin{tabular}{|c|c}
75.0 & 8 \\
to & \\
79.9 & 8 \\
pet. & $\mathrm{p}$
\end{tabular} & $\begin{array}{c}80.0 \\
\text { to } \\
84.9 \\
\text { pet. }\end{array}$ & $\mid \begin{array}{c}85.0 \\
\text { to } \\
89.9 \\
\text { pct. }\end{array}$ & $\left|\begin{array}{c}90.0 \\
\text { to } \\
94.9 \\
\text { pct. }\end{array}\right|$ & $\mid \begin{array}{c}95.0 \\
\text { to } \\
99.9 \\
\text { pct.* }\end{array}$ & $\begin{array}{l}\text { To- } \\
\text { tal }\end{array}$ \\
\hline 0 & 34 & 2 & 8 & 12 & 8 & 3 & 2 & 1 & 1 & 0 & 1 & 0 & 0 & 0 & 0 & 0 & 0 & 0 & 0 & 0 & 0 & 72 \\
\hline $0.1-0.9$ & 6 & 0 & 5 & 3 & 3 & 4 & 1 & 0 & 1 & 1 & 1 & 0 & 0 & 0 & 0 & 0 & 0 & 0 & 0 & 0 & 0 & 25 \\
\hline $1.0-1.9$ & 9 & 0 & 11 & 9 & 8 & 4 & 2 & 3 & 2 & 1 & 0 & 1 & 0 & 1 & 0 & 1 & 2 & 0 & 1 & 0 & 0 & 55 \\
\hline $2.0-2.9$ & 8 & 3 & 1 & 10 & 11 & 2 & 0 & 1 & 0 & 0 & 1 & 0 & 0 & 0 & 1 & 0 & 2 & 0 & 0 & 0 & 0 & 40 \\
\hline $3.0-3.9$ & 1 & 0 & 1 & 3 & 2 & 2 & 3 & 1 & 1 & 1 & 1 & 1 & 0 & 0 & 0 & 1 & 2 & 0 & 0 & 0 & 0 & 20 \\
\hline $4.0-4.9$ & 0 & 0 & 0 & 0 & 0 & 0 & 0 & 0 & 1 & 0 & 0 & 0 & 0 & 0 & 1 & 0 & 1 & 1 & 3 & 0 & 9 & 16 \\
\hline $5.0-5.9$ & 0 & 0 & 0 & 0 & 0 & 0 & 0 & 0 & 0 & 0 & 0 & 0 & 0 & 0 & 0 & 0 & 0 & 0 & 1 & 0 & 11 & 12 \\
\hline $6.0-6.9$ & 0 & 0 & 0 & 0 & 0 & 0 & 0 & 0 & 0 & 0 & 0 & 0 & 0 & 1 & 0 & 0 & 0 & 0 & 0 & 1 & 7 & 9 \\
\hline $7.0-7.9$ & 0 & 0 & 0 & 0 & 0 & 0 & 0 & 0 & 0 & 0 & 0 & 0 & 0 & 0 & 0 & 0 & 1 & 0 & 0 & 0 & 3 & 4 \\
\hline $8.0-8.9$ & 0 & 0 & 0 & 0 & 0 & 0 & 0 & 0 & 0 & 0 & 0 & 0 & 0 & 0 & 0 & 0 & 0 & 0 & 0. & 0 & 3 & 3 \\
\hline Total & 58 & 5 & 26 & 37 & 32 & 15 & 8 & 6 & 6 & 3 & 4 & 2 & 0 & 2 & 2 & 2 & 8 & 1 & 5 & 1 & 33 & 256 \\
\hline
\end{tabular}

* No families in the percentage class 95.0 to 99.9 .

TABLE 3

SEGREGATING AND HOMOZYGOUS $\mathrm{F}_{3}$ FAMILIES, AND EXPECTATIONS BASED ON TWO INDEPENDENT AND ON TWO LINKED GENES

Both expectations based on one dominant and one recessive gene; 28.2 per cent crossover assumed with linked genes

\begin{tabular}{|c|c|c|c|c|c|c|}
\hline \multirow[b]{2}{*}{$\begin{array}{l}\mathrm{F}_{2} \text { classification, } \\
\text { nymphs per day }\end{array}$} & \multirow{2}{*}{$\begin{array}{l}\text { Number } \\
\text { of } \mathrm{F}_{2} \\
\text { plants }\end{array}$} & \multicolumn{5}{|c|}{ Number of families in $\mathrm{F}_{\mathbf{3}}$ classification } \\
\hline & & $\begin{array}{l}\text { Homozygous } \\
\text { resistant }\end{array}$ & $\begin{array}{c}\text { Segregating } \\
3: 1 \text { and } \\
\text { higher ratios }\end{array}$ & $\begin{array}{c}\text { Segregating } \\
1: 3\end{array}$ & $\begin{array}{l}\text { Homozygous } \\
\text { susceptible }\end{array}$ & Total \\
\hline $\begin{array}{l}0.1-3.9 \ldots \ldots \ldots \ldots \ldots \ldots \\
4.0 \text { plus } \ldots \ldots \ldots \ldots \ldots \ldots\end{array}$ & $\begin{array}{r}72 \\
140 \\
44\end{array}$ & $\begin{array}{r}34 \\
24 \\
0\end{array}$ & $\begin{array}{r}38 \\
100 \\
0\end{array}$ & $\begin{array}{r}0 \\
16 \\
11\end{array}$ & $\begin{array}{r}0 \\
0 \\
33\end{array}$ & $\begin{array}{r}72 \\
140 \\
44\end{array}$ \\
\hline Observed total. .......... & . & 58 & 138 & 27 & 33 & 256 \\
\hline $\begin{array}{l}\text { Expected, independent } \\
\text { segregation............. } \\
\text { Expected, linked genes, } 28.2 \\
\text { per cent crossover. . . . . . }\end{array}$ & . & $\begin{array}{r}112 \\
95\end{array}$ & $\begin{array}{c}96 \\
102.1\end{array}$ & $\begin{array}{l}32 \\
25.9\end{array}$ & $\begin{array}{l}16 \\
33.0\end{array}$ & $\begin{array}{l}256 \\
256\end{array}$ \\
\hline
\end{tabular}

give rise to $\mathrm{F}_{3}$ families either homozygous for susceptibility or segregating at the ratio of one resistant to three susceptible. This proved to be the case, although they did not occur in the ratio of one homozygous to two segregating families, as would be expected on the basis of independent segregation, but in the ratio of $33: 11$. Sixteen additional $\mathrm{F}_{3}$ families segregated as $1: 3$, these having 0.1 to 3.9 nymphs per day on their $\mathrm{F}_{2}$ parents. The final ratio was thus $33: 27$, which is still far from the $1: 2$ ratio expected.

From the $140 \mathrm{~F}_{2}$ parent plants, on which there had been an average production of from 0.1 to 3.9 nymphs per day, the resulting families might 
reasonably have been expected to fall in the group segregating $3: 1$ and higher ratios, with a few families homozygous for resistance (because occasional nymphs appeared on the resistant parent). In the main, these expectations were realized (table 3 ), although there were 16 families which segregated one resistant to three susceptible. (These were mentioned in the previous paragraph.)

Of these 16 heterozygous susceptible families, 11 were clearly evident. The other 5 were judged to belong to this group on the basis of the degree of resistance exhibited by the resistant segregates, a point that will be discussed later. Three of these 5 fell in the 45.0-49.9 per cent class and 2 in the 50.0-54.9 per cent class (table 2). The record of the $16 \mathrm{~F}_{2}$ parents of these families is of interest : 1 fell in the $0.1-0.9$ class, 6 in the $1.0-1.9$ class, 4 in the $2.0-2.9$ class, and 5 in the 3.0-3.9 class. Therefore, no point is indicated which clearly separates the homozygous and heterozygous susceptibles from other genotypes. While the criterion of four did screen out all the homozygous susceptible $\mathrm{F}_{2}$ plants, it separated only about two thirds of the heterozygous susceptibles. If a lower point is taken, some other genotypes are included.

The 24 homozygous resistant families from the $\mathrm{F}_{2}$ plants of this $0.1-3.9$ group came from all classes of nymph production represented in it. They were distributed as follows : 6 from $0.1-0.9$ class, 9 from the $1.0-1.9,8$ from the 2.0-2.9, and 1 from the 3.0-3.9 classes.

The $72 \mathrm{~F}_{2}$ plants on which no nymphs were produced gave rise to families which were either homozygous for resistance or were segregating in the range of $3: 1$ or higher ratios. This relation is in line with expectations, since the $10 \mathrm{~F}_{1}$ plants tested were highly resistant. As the old technique was used with the $\mathrm{F}_{1}$, no direct comparisons can be made.

The 27 families segregating one resistant to three susceptible plants (table 3 ) indicate the presence of a recessive factor for resistance. These families had 602 plants, of which 439 , or 72.9 per cent, were susceptible. The resistant plants in these families were only intermediate in resistance. With one or two exceptions, all supported a population of nymphs, which in some cases approached that of the lower limits of susceptible plants.

There is ample evidence of the presence of a dominant gene for resistance, although families segregating in the ratio of three resistant to one susceptible cannot be distinguished from those segregating for a dominant and a recessive gene, thus giving a $13: 3$ ratio.

The proportion of segregating to homozygous families observed is not in accordance with independent segregation, as may be seen in table 3 . This is especially noticeable in the proportion of susceptible families to those segregating in the ratio of $1: 3$. Linkage would bring about such a relation. Since only 58 of the $256 \mathrm{~F}_{3}$ families, or $22.7^{\prime}$ per cent, were resistant-hardly enough to satisfy the hypothesis of a single dominant resistant gene-we did not expect to find a crossover value that would permit a satisfactory fitting with all classes. There were 33 susceptible families in a population of 256 , a relation which would result from a crossover of 28.2 per cent. The expected reaction of $\mathrm{F}_{2}$ plants and segregation of $\mathrm{F}_{3}$ families on this basis are given in figure 1 , and the expected numbers for the population under consideration are shown in table 3 . 
While the divergence between observed and calculated numbers by the foregoing theory is statistically significant, it is not so great as that obtained from a number of other genetic theories considered. A few additional points follow which support the theory advanced.

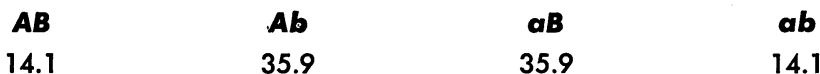

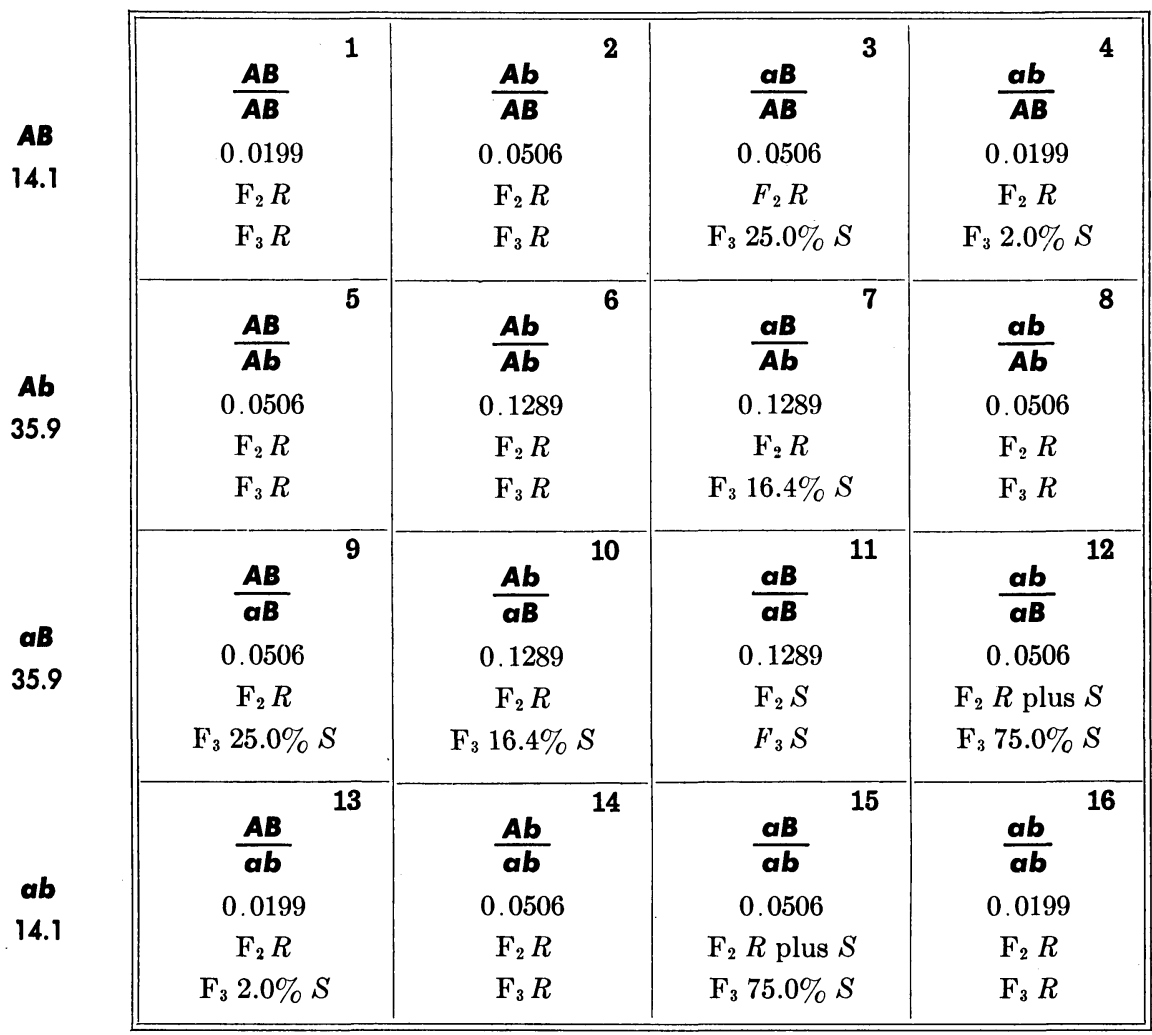

Fig. 1. Diagram of expected $\mathrm{F}_{2}$ reaction and $\mathrm{F}_{3}$ segregation for resistance $(R)$ to aphids in alfalfa on the basis of a dominant $(A)$ and a recessive $(b)$ resistant gene, which are linked with a crossing over of 28.2 per cent. Value obtained from the $256 \mathrm{~F}_{2}$ plants from which $\mathrm{F}_{3}$ progenies in groups $a B A b$ and $A b a B$ were grown allows for the misclassification of about two thirds of the heterozygous susceptibles. Resistant plants in group $a b a b$ almost without exception support a small population of aphids.

As pointed out earlier, the resistant plants in families segregating in the ratio of $1: 3$ were somewhat intermediate in resistance. They supported nymph populations ranging from a few to numbers approaching the lower limits of the susceptible checks. Therefore, families of the genetype $a a b b$ (cell 16, fig. 1) should be intermediate, or without completely resistant plants. Four such families were found where 5.1 were expected.

The total number of $\mathrm{F}_{3}$ families segregating out the lower percentages of 
bunt expected from cells $3,4,7,9,10$, and 13 conforms very well to the hypotheses under consideration. In these, there were 578 susceptible plants out of a total population of 3,674 , or 15.7 per cent. The average per cent expected from these families, according to figure 1, is 17.1.

The homozygous resistant families are too few to support the above hypothesis. In fact, as noted earlier, there are hardly enough to satisfy the hypothesis of a single dominant gene. The question arises as to whether this is a chance deviation or a result of incorrect classification of some of the families. There is a corresponding excess of families among those classified as segregating for $3: 1$ and higher ratios. It will be recalled that one resistant parent plant (table 1) had a fairly high population of nymphs. It was also pointed out that some plants, homozygous for the recessive gene only, supported populations approaching the lower limits of the homozygous susceptible plants. This fact suggests that there might have been some incorrect classifications, especially in families arising from $A a b b$, genotypes where one fourth of the population would be intermediate. However, every effort was made to guard against incorrect classifications by retesting susceptible plants in segregating families if there was any doubt about their susceptibility. Certainly the entire deficit was not likely to be accounted for in this way. There is no evidence that the 256 families did not represent a random sample. Nor is there reason to believe that homozygous resistant plants did not seed as readily as others.

\section{DISCUSSION AND CONCLUSIONS}

The development of insect-resistant crops presupposes the discovery of resistant varieties or selections. If it becomes necessary to breed a variety suited to some particular area, a knowledge of the genetics of resistance is essential to a well-planned and intelligent breeding program.

A necessary adjunct to a study of resistance is a suitable method of testing that will not only distinguish between resistant and susceptible plants but will also distinguish between different levels of resistance. The procedure used here-that of caging one second-instar nymph of the pea aphid with each plant-was satisfactory for detecting homozygous susceptible plants. Only about one half of the heterozygous susceptible plants resulting from the action of a recessive resistant gene, however, fell in the susceptible group in $\mathrm{F}_{2}$, as determined by progeny tests. It was felt that the above procedure gave a fairly accurate classification of $\mathrm{F}_{3}$ families.

The $\mathrm{F}_{3}$ data clearly indicate the presence of a recessive resistant gene. At least one, and probably only one, dominant gene also is present. This proportion of homozygous to heterozygous families suggests the presence of linkage with a crossover value of about 28 per cent indicated.

For no apparent reason there was a deficiency of homozygous resistant families and a corresponding excess of heterozygous families. This divergence could not be explained on the basis of linkage or any other genetic theory tried.

Comparatively few genetic studies have been made with alfalfa, and frequently those have been a by-product of some other problem. For the most part, the data have not yielded the simple genetic ratios usually found in 
other crops. The chromosome number in common alfalfa indicates that it is a tetraploid. Recently Tysdal, Kiesselbach, and Westover (1942) suggested that it is an autotetraploid, and that some segregation products found may be explained on the basis of random chromatid segregation. This theory did not apply in the case of aphid resistance.

Along with this genetic study, we have made satisfactory progress in breeding an aphid-resistant alfalfa of the Common Chilean type. Although the project is not yet completed, there is every reason to believe it will be successful.

\section{BIGGER, JOHN H.}

\section{LITERATURE CITED}

1943. Insect resistance in corn. Amer. Soc. Agron. Jour. 35 :689-94.

BlaNCHARD, RALPH A.

1943. Insect resistance in forage plants. Amer. Soc. Agron. Jour. 35:716-24.

Blanchard, Ralph A., and John E. Dudley.

1934. Alfalfa plants resistant to the pea aphid. Jour. Econ. Ent. $27: 262-64$.

DAHMS, R. G.

1943. Insect resistance in sorghum and cotton. Amer. Soc. Agron. Jour. 35:704-15.

JoNes, Elmer T.

1943. Insect resistance in wheat. Amer. Soc. Agron. Jour. 35:695-703.

Painter, Reginald H.

1943. Insect resistance of plants in relation to insect physiology and habits. Amer. Soc. Agron. Jour. 35:725-32.

Tysdal, H. M., T. A. Kiesselbach, and H. L. Westover.

1942. Alfalfa breeding. Nebraska Agr. Exp. Sta. Res. Bul. $124: 1-46$. 

The journal Hilgardia is published at irregular intervals, in volumes of about 600 pages. The number of issues per volume varies.

Subscriptions are not sold. The periodical is sent as published only to libraries, or to institutions in foreign countries having publications to offer in exchange.

You may obtain a single copy of any issue free, as long as the supply lasts; please request by volume and issue number from:

\section{Publications Office \\ College of Agriculture \\ Berkeley 4, California}

The limit to nonresidents of California is 10 separate issues on a single order. A list of the issues still available will be sent on request. 